\title{
O Bestiário de Nemésio ou como escrever uma Zoopoética açoriana
}

\author{
The Bestiary of Nemésio or how to write an Azorean zoopoetic
}

\author{
ANNA SILVA \\ 1Universidade dos Açores (UAç), Ponta Delgada. Iha de São Miguel, Portugal.
}

Resumo: Para problematizar o antropocentrismo epistémico, encontramos nas últimas décadas do século XX e início do século XXI o desenvolvimento de um novo campo de investigação denominado Estudos Animais. Neste novo campo, o enfoque das investigações entrecruza várias linhas de pesquisa em ciências humanas e biológicas abarcando tanto a bioética e a biopolítica como as reflexões históricas, antropológicas, filosóficas e literárias. Entre os autores pioneiros que buscaram desconstruir e reconfigurar fora da esfera do antropocentrismo o próprio conceito de humano, constituem referências importantes para o desenvolvimento do presente estudo as teses defendidas pelo filósofo Georges Bataille. No que tange à literatura, meu interesse recai sobre a poesia de Vitorino Nemésio que, de forma instigante, propõe novas maneiras de pensar as complexas e controversas relações entre homens e animais não humanos.

Palavras-chave: antropocentrismo; estudos animais; Nemésio; Bataille.

\begin{abstract}
In order to problematize epistemic anthropocentrism, we find in the last decades of the 20th century and the beginning of the 21st century the development of a new field of research called Animal Studies. In this new field, the research approach intersects several lines of research in the human and biological sciences, encompassing both bioethics and biopolitics, as well as historical, anthropological, philosophical and literary reflections. Among the pioneer authors who sought to deconstruct and reconfigure the very concept of human being outside the sphere of anthropocentrism, the theses defended by the philosopher Georges Bataille are important references for the development of the present study. As far as literature is concerned, my interest rests on the poetry of Vitorino Nemésio, who, in an enticing way, proposes new ways of thinking about the complex and controversial relations between men and nonhuman animals.
\end{abstract}

Keywords: anthropocentrism; animal studies; Nemésio; Bataille. 


\section{Introdução - Questões de Zooliteratura e Ontologia}

O Homem é a medida de todas as coisas, assim escreveu Protágoras de Abdera, filósofo grego pré-socrático, no século V a.C. (Fragmento: DK 80 B1).

Com esta célebre frase, a filosofia demarcou todo o seu discurso antropocêntrico. De Protágoras a Heidegger, da história da filosofia grega à história da filosofia contemporânea, a discussão remete-nos a um lugar da cultura: o tópos do antropocentrismo epistémico que afirma que os seres humanos estão condenados a ver o mundo como somente os humanos podem ver, visto que, o mundo dos animais, ou da animalidade, é totalmente inacessível, fechado para nós. Esta delimitação epistemológica reduz as possibilidades do que pode ser pensado sobre o ser dos outros animais e, também, restringe o que pode ser pensado sobre a animalidade do ser humano e seu processo de hominização.

Para problematizar o antropocentrismo epistémico, encontramos nas últimas décadas do século XX e início do século XXI o desenvolvimento de um novo campo de investigação denominado Estudos Animais ou Zooliterários. Os estudos zooliterários têm como foco principal repensar a relação entre homem e animal na literatura, considerando a mudança dos paradigmas que direcionam a distinção entre mundo civilizado e mundo selvagem ${ }^{1}$. Neste novo campo, o

\footnotetext{
Como indicam em suas recém-publicadas investigações: Maria Esther Maciel, investigadora pós-doc do Centro de Estudos Humanísticos (CEHu) da Universidade dos Açores. Bolsista da Direção Regional da Ciência e Tecnologia (DRCT), referência nos estudos zooliterários no Brasil e professora da Universidade Federal de Minas Gerais, e Márcia Neves, investigadora pós-doc do Instituto de Estudos de Literatura da Faculdade de
}

enfoque das investigações entrecruza várias linhas de pesquisa em ciências humanas e biológicas abarcando tanto a bioética e a biopolítica como as reflexões históricas, antropológicas, filosóficas e literárias. Entre os autores pioneiros que buscaram desconstruir e reconfigurar fora da esfera do antropocentrismo o próprio conceito de humano, constituem referências importantes para o desenvolvimento do presente estudo as teses defendidas pelo filósofo Georges Bataille.

No que tange à literatura, meu interesse recai sobre a poesia de Vitorino Nemésio que, de forma instigante, propõe novas maneiras de pensar as complexas e controversas relações entre homens e animais não humanos. Em O Bicho harmonioso e em Cavalo Encantado, tentarei mostrar que é notável a incursão "zoontológica" delineada por Nemésio que constrói interfaces entre a filosofia e a literatura ao ultrapassar as circunscrições metafóricas e o paradigma da fábula, inaugurando uma "zooliteratura" capaz de descrever a humanidade e a animalidade não mais em termos de oposição hierarquizada, mas em termos de complementaridade. Para articular poesia e prosa, ou seja, para aproximar o sentido da reflexão filosófica e o alcance da criação poética no interior da vasta produção literária nemesiana, utilizarei como textos de apoio a coletânea de artigos, ensaios e conferências intitulada Sob os Signos de

\footnotetext{
Ciências Sociais e Humanas da Universidade Nova de Lisboa. Ambas dedicam suas minuciosas análises aos bestiários lusófonos escritos por: Miguel Torga, Herberto Helder, Clarice Lispector, Guimarães Rosa, Aquilino Ribeiro entre outros. Elas observam que os Estudos Animais ou Zooliteráriospossuem duas grandes vertentes de investigação: a que diz respeito ao animal propriamente dito e à chamada animalidade e a que se dedica em pensar e escrever as complexas e controversas relações entre homens e animais não humanos. Cf: Maciel, 2011; Neves, 2016.
} 
Agora e o célebre prefácio Da Poesia escrito especialmente para a edição da coletânea de seus escritos poéticos.

\section{Nos confins do humano ou a passagem das fronteiras entre animalidade e humanidade}

Descrever o nosso mais profundo passado, explicar os fundamentos das condutas humanizadas que separaram o ser humano do animal, ou ainda, tentar surpreender o momento no qual o animal se transformou em ser humano, eis os temas a serem abordados e entrelaçados a partir de lugares teóricos diversos. É interessante notar que em filosofia e em literatura encontramos, desde os textos fundadores da nossa tradição cultural, paradigmas que estabelecem a grande divisão entre conceito e metáfora quando entra em cena o debate acerca da concepção que a humanidade tem de si mesma e do seu pensamento a partir do território identitário atribuído aos animais ${ }^{2}$.

Neste debate, dois pontos requerem atenção particular: primeiro, trata-se do grande esforço de aproximação entre discurso filosófico e discurso poético empreendido pela filosofia contemporânea francesa e pela literatura pensante de Vitorino Nemésio. Segundo: cabe discutir,

\footnotetext{
2 Élisabeth de Fontenay, professora da Universidade de Paris, publicou uma extensa e exaustiva pesquisa sobre o tema da questão animal e sua abordagem ao longo da história da filosofia. De Platão a Bataille, Fontenay mostra como a cultura filosófica ocidental gerou, com raras exceções, Bataille é uma delas, um sentimento de mal-estar em torno das concepções de animalidade. Mal-estar determinado por uma "postura ontológica" marcada pela verticalidade hierárquica das relações que instituíram entre homens e animais uma "separação irrecusável". Tal separação, segundo Fontenay, serve para justificar os processos de marginalização e coisificação dos animais uma vez que a racionalidade e a linguagem humanas servem como propriedades diferenciais e superiores (1998, p. 21-24).
}

nos domínios da travessia das fronteiras entre humanismo e naturalismo, a dimensão da representação ontológica dos animais no texto nemesiano, seu alcance e seus limites.

Tradicionalmente, o contraste fundamental estabelecido entre humanidade e animalidade exige que façamos uma distinção muito nítida entre o ser humano e o animal. Há aqui uma configuração que requer uma discussão situada tanto no contexto de um engajamento existencial concreto, dedicado, por exemplo, à luta pelos direitos dos animais, como no plano difundido pelas produções discursivas onde a vida animal é, muitas vezes, classificada como mera metáfora, fábula ou paródia. Isso significa, naturalmente, que essas demarcações evidenciam um ponto de vista restrito sobre animalidade e antropocentrismo que merece ser discutido e questionado. É, portanto, da valorização da experiência ficcional e biográfica no plano da animalidade questionadora do humano que trata a nossa investigação: é um certo homem no animal e um certo animal no homem que é aqui visado, sem identidades ontológicas definidas e definitivas.

Neste sentido, a abordagem de Nemésio é representativa de uma tendência incomum entre filósofos e poetas que lidam em seus escritos com as relações entre homens e animais. Sob esse prisma de ruptura, Nemésio desenvolveu todo um pensamento da "diferença", em consonância com o neologismo derridiano - différance, estabelecendo uma "inquietante" estranheza ao sinalizar em seus escritos a natureza animal como o experimentar o ser outro, promovendo o questionamento do humano por meio do não humano - a simbolização da 
alteridade mais radical ${ }^{3}$. O poeta expande, assim, os recursos da linguagem poética e das categorias conceituais filosóficas ao incursionar pela poética das "totalidades ônticas", como ele mesmo afirma no prefácio Da Poesia, destinado a oferecer aos seus leitores uma teoria da essência da sua atividade poética:

Sobre o que define o poético, frente ao metafísico, estamos, todavia, mais seguros. Se o pensamento filosófico apreende a realidade na relação do juízo, o que se possa chamar o pensamento poético indica-a ou mostra-a pela mediação de uma realidade segunda, substitutiva ou simbólica, que a razão não traduz absolutamente nos seus termos, mas que verbalmente é dada com a plenitude da intuição. A poesia desvenda, quanto mais não seja, um véu, da interposição de outros véus. E se parece mover-se num círculo perpétuo de conversões e de reversões de sentido, é que a realidade a que abre acesso é em si mesma um desferir infinito de mútuas alusões dos "demonstrados" que a têm. Ela é a realidade do que o horizonte poético assinala e descobre: isto, aquilo, este, o além: a pluralidade de um uno que constantemente se remete para sua multiplicação infinita (2006, p. 119).

Nessas articulações não lineares e frontais entre filosofia e poesia, apreender e narrar o real consiste em avançar rumo a um despojamento da sua unidade

\footnotetext{
3 A poesia de Vitorino Nemésio, a meu ver, estabelece um profícuo diálogo com a filosofia de Derrida. Poeta e filósofo dedicam-se a interrogar o primado do sentidofundado na oposição metafísica: fala/escrita, significado/significante. Para ultrapassar as limitações das oposições binárias e dicotómicas, poeta e filósofo exploram uma remessa infinita de significantes. Assim, opera-se uma desconstrução dos pilares sobre os quais a metafísica aparece erigida a partir de uma hierarquização conceitual muito violenta que relega o singular, o sensível, o aparente, ao poder soberano do universal, do inteligível e da essência.
}

ontológica, desnudando o núcleo vivo do narrável: a matéria polifônica e polimórfica com a qual deparam-se poetas e filósofos. É como se os textos metafísicos e poéticos, ao pôr em questão as várias maneiras possíveis de apreender e de dizer o real, estivessem insistindo na importância de designar um fato, um ponto, uma história individual ou uma singularidade qualquer como o lugar de trânsito, o território por onde atravessam múltiplos juízos e múltiplas formas de ser e de narrar.

Ainda no mesmo prefácio, Nemésio sugere que a linguagem é sempre híbrida e, por isso, é possível recuperar o elo intrínseco entre as "construções regidas pelo conceito" e as "representações alegóricas e simbólicas", ou seja, é possível aproximar filosofia e poesia:

O filósofo deixa em suspensão o que não pode captar na rede do rigor das ideias: o poeta afirma precisamente $\mathrm{o}$ que suspende na indeterminação do enigmático. Ambos travam assim, com armas desiguais, luta idêntica. A guerra do idêntico verte diversamente um só sangue. Do campo comum de temas da metafísica e da poesia levantam-se como tópicos - o Ser, o Nada, o Tempo, a Morte (2006, p.119-120).

Arrancados da assepsia do campo das ideias, jogados numa espécie de arena de gladiadores, encontramos filósofo e poeta a partilharem uma convivência visceral. Através da discussão das intricadas relações ontológicas, seja pela via do Ser ou dos devires do Tempo, seja pela tentativa ilusória de figuração do Nada ou da Morte, o registro poético-filosófico se faz sempre como um desafio à imaginação, visto que, o que não pode ser pensado em conceito ou narrado em palavras, deve ser imaginado. E essa abertura imaginativa-criativa acaba 
estimulando, por extensão, a produção de um pensamento crítico-teórico, também aberto e transversal, comprometido com a construção de um novo paradigma que estimula a repensar a complexidade de todas as formas de existência.

Mas, para além dos possíveis diálogos entre discurso poético e discurso filosófico, encontramos em Nemésio uma pulsão demorada, detalhada e individualizante de autobiografia que encontra no animal a potencialidade de uma partilha ontológica de sentidos encarnados em poemas, histórias e reflexões singulares. Nas palavras de Nemésio:

De O Bicho Harmonioso direi, como o próprio símbolo diz: É esse o meu duplo lírico, animal fabuloso, que me elucida das minhas aspirações profundas amores, cuidados, sonhos, o mundo perdido da infância - o "ovo que deixei, bicado e quente, / vazio de mim, no mar" / "E que ainda hoje deve boiar, ardente/ Ilha, / E que ainda hoje deve lá estar".

A esse respeito, creio que o poema central do livro e, em grande parte, do que, não sem tal ou qual ênfase, poderei chamar toda a minha obra poética, é O Canário de Ouro: ainda e sempre bicho harmonioso, bestiola de fábula, como o licorne ou a fénix (NEMÉSIO, 2006, p. 124).

Convém observar que tal pulsão autobiográfica produz a sobreposição da imagem da animalidade fundamentalmente pensada como essencial para a caracterização do animal humano e da humanidade representados pelo próprio poeta. Sob esse prisma, Nemésio definese como "bicho harmonioso", "animal fabuloso" capaz de enxergar os limites abissais do humano ao sair do seu ovoilha como canário de ouro, cantador de fabulações. Interessante observar que o poeta não apenas confronta o humanismo antropocêntrico, mas realiza, no corpo da sua escrita poética, um encontro, ainda que fictício, entre o humano e sua outridade/ alteridade animal. Uma experiência que passa, assim, pela transposição das fronteiras entre o humano e o não humano rumo ao "animal fabuloso" que elucida o poeta sobre os seus saberes acerca de si mesmo, da sua arte poética, do mundo e da humanidade. Nesse encontro-identificação com a voz de um "eu-pássaro", o canário de ouro, Nemésio cita aquele que ele considera ser seu mais emblemático poema, abrindo, desse modo, a possibilidade de pensar e poetizar o animal sem subestimá-lo à soberania humana e sem reduzi-lo à categoria de uma alegoria metafórica, uma espécie de adorno do poema.

É justamente a partir dessa possibilidade de refletir e narrar, poeticamente, o fundamento último da experiência da animalidade, comunicadora do mistério da diferença humana, que sugerimos aqui uma associação entre o bestiário imaginário de Vitorino Nemésio e a filosofia de Georges Bataille.

\section{Arte (e) Poética Animalista: A Estética da Zoo-Antropogénese em Nemésio e Bataille}

Começo pelo começo da história da "humanidade consumada" descrita por Bataille em seu belo livro: Lascaux ou o Nascimento da Arte. O que nele lemos, remete-nos para as pinturas rupestres da caverna de Lascaux, acidentalmente descoberta em 1940 e visitada em 1955 pelo filósofo. O entusiamo da visita levou Bataille a escrever sobre as renas, os touros, 
os bisontes e os cavalos representados com perfeita minúcia por homens e mulheres portadores de uma "racionalidade recente", recém apartados da irracionalidade dos outros animais e que, pela primeira vez, enfatiza o filósofo, "fizeram obra de arte":

A caverna de Lascaux que data, sem dúvida, da primeira parte da idade a que a Pré-História chamou Paleolítico Superior, devido a estas condições situa-se no começo da humanidade consumada. Qualquer começo pressupõe aquilo que o antecede, mas é ponto assente que o dia nasce da noite, e a luz que nos chega de Lascaux é a aurora da espécie humana. (...) Em Lascaux, o que nos alucina e transfigura é a visão do mais distante. $\mathrm{E}$ ainda por cima esta mensagem é agravada por uma desumana estranheza. Vemos uma espécie de ronda, uma cavalgada de animais que se perseguem nas paredes. Mas uma tal animalidade não deixa menos de ser o primeiro sinal quetemos, o sinal cego e, no entanto, o sinal sensível, da nossa presença no universo" (BATAILLE, 2015, p. 15-16).

Quando se entra em contato com a teoria da antropogénese de Bataille, o sentimento que vivenciamos é o de estranhamento, de perturbação diante da dramatização de uma ordem causal e determinista, familiar e natural, que também expressa a perda dos critérios de individuação que nos impossibilitam identificar e reconhecer uma síntese possível do animal e do homem. Assim como na poesia de Nemésio, em que somos confrontados com os limites da possibilidade de narração do "eu-humano" que narra na voz do "eupássaro" e, portanto, confrontados com os limites da linguagem, na teoria de Bataille, da mesma forma, estamos impossibilitados de narrar o que se passa nas fronteiras da animalidade tendo em vista o domínio conceitual, filosófico. Em ambos os casos, a confrontação dos limites do entendimento humano expressa mais uma necessidade de ampliar a capacidade de entender e interrogar o vivente, oferecendo formas de imaginar novas virtualidades e realidades entre animais humanos e não humanos, do que um constrangimento anunciador do inefável, do inenarrável. Encontramo-nos, com efeito, numa esfera em que a exatidão com que se narra conceitualmente ou poeticamente é relevante para resgatar a essência da memória de uma herança cultural arquetípica que nos remete "mais adiante do que é possível," "no domínio do mais profundo passado". Contudo, não é demais lembrar que, a mesma exatidão narrativa torna-se absolutamente irrelevante para a compreensão das categorias lógicas e das classificações culturais pré-estabelecidas no quadro das ciências descritivas e indutivas como a biologia, a paleontologia, a etologia e a psicologia, sobretudo quando estas ciências se dedicam a estudar a história e o comportamento dos diversos tipos de animais a partir da utopia romântica do paradigma civilizatório ${ }^{4}$.

\footnotetext{
Para o filósofo francês Michel Onfray, a utopia romântica remonta à tradição dos bestiários medievais que, por sua vez, remontam ao "romance religioso" narrado pelo Gênese veterotestamentário. Tomando como ponto de partida a passagem 1.26 do Gênese, onde Deus diz que o homem foi feito a sua imagem e semelhança para dominar todos os animais existentes sobre a Terra, o filósofo assinala a compatibilidade do "regime ontológico judaico-cristão" com a tradição da história da literatura ocidental. Seu argumento mais eloquente é inspirado nas polêmicas instauradas pelos padres apologistas. No século III d.C., Orígenes é o representante mais corrosivo destas controvérsias. Orígenes mostra, ao polemizar contra Celso, como os animais devem ser vistos sob o paradigma moral e religioso. Para este fim, um "dualismo" deve ser instaurado para separar os "animais positivos" dos "animais negativos". Assim, entre os vários exemplos elencados por Orígenes, encontramos no cordeiro o símbolo do sacrifício de Cristo enquanto vemos na serpente a imagem demoníaca do pecado. Desta forma, assinala Onfray, Orígenes sistematizou "evangelicamente" o nosso imaginário (2015, p. 303-310).
} 
É assim que poeta e filósofo reconstroem a imagem da animalidade que nossa humanidade abandonou. As mais de mil e novecentas pinturas de animais que decoram há vinte mil anos a caverna de Lascaux revelam, assim como veremos no bestiário nemesiano, uma arte animalista. Como as linhas anteriormente citadas já sugeriram, as pinturas de Lascaux deixam o testemunho de uma "desumana estranheza". Faltam nelas, observa Bataille, as representações de figuras humanas. Das muitas centenas de figuras de animais pintadas com traços esteticamente sofisticados, revelando a "vontade de prodígio" de seus autores, paleolíticos artistas, muitas delas aparecem configuradas no formato de cenas dotadas de autonomia narrativa e, apenas uma delas, retrata uma criatura semi-humana que possui corpo de homem e cabeça de pássaro. O que o filósofo nos tem a dizer acerca dessa humana ausência? Como explicar o primeiro "sinal cego e sensível" que pela primeira vez registrou a nossa essência humana com a dignidade estética que define toda obra de arte? Ou ainda: como explicar esta visão humana da animalidade transfigurada nos afrescos de Lascaux?

Para tentar resolver estas questões, vamos voltar nosso olhar para a narrativa da antropogénese habilmente construída por Bataille perante as pinturas de Lascaux. Em seguida, iremos sugerir um entrelaçamento entre a antropogénese do filósofo e a zooantropogénese do poeta, fazendo convergir domínios de reflexão que separaríamos em nome das ciências naturais, da lógica e dos discursos demonstrativos.

Tomo como ponto de partida o argumento central da tese de Bataille. Segundo o filósofo, os vestígios da pré- história da humanidade grafados em Lascaux anunciam as consequências do rompimento instituído pelo ser humano na ordem da natureza, ou seja, sinalizam a presença de uma "descontinuidade"5. Num primeiro momento, a atividade utilitária e objetiva ligada ao fabrico de instrumentos instituiu o mundo do trabalho, invenção do "engenho" do homo faber, também conhecido como homem de Neandertal. Por seu turno, observa nosso autor, com o decorrer de centenas de séculos, o desabrochar da atividade estética coincidiu com o aparecimento do homo sapiens", criador de uma "arte rica", ligada à atividade mágico-religiosa que, assim como o trabalho, instituiu uma "descontinuidade" na percepção da ordem natural (2015, p.35-40). Seguindo tal contraposição de ideias, o dinamismo da história pré-antropológica vislumbrada nas pinturas rupestres de Lascaux redunda num novo paradigma. Quer isso dizer,

\footnotetext{
Também podemos interpretar o tema da "descontinuidade" articulando-o com o tema da "imanência" analisado por Bataille no livro Teoria da Religião. Neste livro, Bataille, ao afirmar que a existência do animal no mundo é "imanente", situa, no polo oposto, a existência humana que aparece definida sob o signo da "transcendência". Assim sendo, a imanente forma de vida do animal está em perfeita continuidade com os fenômenos e com os objetos que o cercam, visto que, o animal é incapaz de transcender o próprio ambiente e postular-se como distinto do seu entorno. Por esta razão, o animal difere do ser humano, pois não pode perceber a duração de um objeto, sua existência no tempo (2003, p. 21-23).

6 Bataille utiliza as teorias pré-históricas sobre o homo sapiens e o processo de hominização que foram publicadas, em meados do século XX, pelo Padre Henri Breuil, reconhecido arqueólogo francês. Recentemente, a tese do Padre Breuil foi refutada. Uma equipe de arqueólogos formada por investigadores alemães, portugueses e espanhóis descobriram, na região da Extremadura, uma caverna cujas pinturas rupestres possuem mais de 64.000 anos. Um recuo no tempo que faz com que os Neandertais entrem em cena como os autores do primeiro registro artístico. A descoberta foi publicada em fevereiro deste ano na conceituada revista Science. Cf: U-Th dating of carbonate crusts reveals Neandertal origin of Iberian cave art. Science, 23 Feb. 2018, p. 912-915. Consulta on-line: <http://science. sciencemag.org/content/359/6378/912>.
} 
na interpretação de Bataille, que pelo trabalho e pela arte o homem separouse definitivamente do animal. Ambos instituíram na consciência humana o acesso a dois tipos de objetos: "uns presentes e outros por chegar". Ou seja: a matéria de que são feitos os objetos e a sua posterior transformação pelo trabalho cuja ação "suprime" e "assegura" a materialização do que será fabricado determinaram a inserção de uma "descontinuidade" na ordem natural. Nessa perspectiva interpretativa, o trabalho e a arte serão considerados os elementos catalisadores que possibilitaram o surgimento da linguagem:

No momento em que a designação do objeto refere implicitamente a matéria de que é feito e o trabalho aparece como um primeiro estado em que o seu emprego suprime a matéria e assegura o objeto, é possível a linguagem clara para lá do ladrar do desejo. A partir daí a linguagem situa-se perduravelmente na passagem do tempo. Mas o objeto extirpa da sensibilidade imediata aquele trabalho que o enuncia. $\mathrm{O}$ homem reencontrará o sensível se, para lá das obras úteis, criar com o seu trabalho uma obra de arte (BATAILLE, 2015, p. 41).

Percebe-se bem aqui como a relação entre o estatuto civilizatório do trabalho e a sua conversão em arte e em linguagem conferem a superioridade do ser humano no domínio técnico. Mas não é somente o privilégio da mestria técnica que fundamenta a conduta humana. Chega o momento de pagarmos o preço e arcarmos com as consequências oriundas das técnicas desnaturalizadas e desnaturalizantes. O drama da antropogénese de Bataille passa agora a expressar a diferença entre o animal humanizado e o animal não humano contrapondo o "domínio técnico" ao "domínio mágico". Isso significa que: se o homem possui a supremacia da técnica, o animal lhe é superior no "domínio mágico" por estar em contato direto com a natureza, afastado da "descontinuidade" que marca a condição humana.

A magia é sempre a conduta do homem à procura de um resultado interessado, mas isto sucede enquanto ele reconhecer nessa procura a sua impotência, imputando a omnipotência ao mundo onde a técnica já não funciona, já não tem poder, ao mundo das forças irredutíveis da natureza, das quais a sorte depende. A operação mágica anuncia uma primazia na ordem dos valores: o do sagrado sobre o profano, das desordens do desejo sobre o cálculo da razão, da sorte sobre o humilde mérito e do fim sobre os meios. (...) Dito de outra maneira, a atividade profana é o meio e o momento sagrado é o fim. Desde o princípio, o divino foi a significação profunda do humano. A operação mágica é a conduta de um homem que empresta ao mundo do fim, divino (ou sagrado), mais força e verdade do que ao mundo laboral dos meios: este homem inclina-se perante um poder que o excede, que é soberano, tão estranho à atitude humana do trabalho como o animal pode sê-lo a expressão (BATAILLE, 2015, p. 86).

Aqui o discurso filosófico sobre a antropogénese serve para mostrar uma experiência que sintetiza a união do mundo moral com o mundo da natureza. Com a experiência dessa visão unificada da realidade, estamos na presença de outra dimensão da perspectiva filosófica que expõe a decisão e a opção por um modo de vida que reconhece no sagrado um valor soberano. É como se a experiência do sagrado como realidade suprema invadisse o animal humano com sua presença transformadora e ordenadora. 
É por meio dessa assimilação unificadora e privilegiada da ordem da natureza que Bataille confere sentido e fundamentação à conduta humana eticamente dignificada.

Aliás, não deixa de ser revelador que a certeza da incompatibilidade entre o "domínio técnico" e o "domínio mágico" conduza o filósofo a conceber a "interdição" como uma não-conduta em que cada ser humano reconhece uma penosa falta cometida a partir da "descontinuidade" que ele próprio inseriu na ordem da natureza. Assim, Lascaux representa, simultaneamente, o mundo que viu o desabrochar da experiência estética, o desabrochar da linguagem (crono)logicamente ordenada e, por fim, o mundo que "ordenou o sentimento do interdito". Como argumenta Bataille:

Se os animais se distinguem claramente do homem, talvez o façam com maior clareza nisto: nunca haver nada, para um animal, que seja interdito; só a circunstância natural o limita, em nenhum caso se limita por si próprio (BATAILLE, 2015, p. 93-94).

Parece-me modelar este trecho, na medida em que mistura, não indiscriminadamente, mas intencionalmente, a explicitação da soberania da liberdade animal com o humano constrangimento do interdito. Existe em tal mistura uma relação mútua que induz, de forma contrastante, à compreensão de que o contato direto do animal com as forças da natureza, em oposição ao esforço humano regrado e laborioso, levaram os paleolíticos artistas de Lascaux a atribuírem aos animais que eles figuraram uma superioridade digna de deuses e de reis. A rigor, esse reconhecimento sobre os ditames do interdito, necessários para a manutenção do mundo organizado do trabalho, aqui profundamente enraizados na tese da antropogénese, segue uma motivação que indica que o prodígio do Belo produzido pela obra de arte é o único fim desejado pela recém-nascida humanidade. Essa motivação parece-me agudamente representada quando o filósofo enfatiza que é graças ao "admirável recreio da arte," que alivia o animal humano das frequentes fealdades advindas da sua precária condição, que o sentido da vida humana é ligado ao da arte. Nisto reside, a meu ver, o nó da evolução: é indiscutível que o prodígio do Belo artisticamente criado nos libertou, nos momentos de recreio/recriação, da triste necessidade imposta pelo trabalho. Assim, vê-se como se configuram as limitações que foram inseridas pela imperatividade do interdito e como elas foram superadas pela magnificência da criação estética. É na retomada desta configuração que o filósofo infere que a culpa pela desordem inserida no mundo do trabalho seja agora transferida para a inflexibilidade da ordem da natureza. Paradoxal (des)ordem que leva o filósofo a prever em sua argumentação que a inevitabilidade da morte e da sexualidade representam: "a animalidade em nós perdurável que a vida e a natureza a todo o instante introduzem e são como uma lama de onde saímos".

$E$ isso nos leva às questões acima elencadas. Pois agora podemos começar a ver as razões pelas quais a "arte animalista" de Lascaux revela o complexo jogo de sentimentos e reflexões dos seus pintores que negavam o que eles eram e afirmavam o que eles não eram ao privilegiarem a representação das figuras animais em detrimento das figuras humanas. Assim, a finalidade das pinturas de Lascaux com seus animais belamente representados é 
testemunhar a nostalgia da animalidade. Pondo regras à liberdade sem freios que representa a animalidade perdida e recalcada, a "fastidiosa ordem humana" revela-se nostálgica. Está em causa, a meu ver, a efetivação do reconhecimento da nostalgia. Daí a necessidade de recusar o humano através da sua não figuração expressa através da arte animalista. Como nos mostra Bataille:

Era, portanto, conveniente que não fosse sublinhada em si próprios a humanidade que apenas significava o fraco poder do trabalho e, pelo contrário, sublinhada uma animalidade que irradiava o todo-poder de um mundo impenetrável. (...) Afinal, se conseguissem fazê-lo, de igual forma se furtariam à fastidiosa regularidade da ordem humana; regressariam a este mundo da selvageria, da noite, da enfeitiçante bestialidade; figuramno com fervor, angustiados, deixando por um momento esquecido o que nascia neles e era claro, prosaicamente eficaz e ordenado. Nós próprios experimentamos o peso súbito de uma civilização que, no entanto, nos orgulha muito. Temos sede de uma outra verdade e atribuímos a nossa fadiga a um qualquer erro ligado ao privilégio da razão (BATAILLE, 2015, p. 96).

Por certo, como anuncia Bataille, a humanidade nascente deu mais valor à forma animal do que à forma humana. Esse é o alicerce das pretensões de validade da tese do filósofo que procura emitir justificativas válidas para a fundamentação da conduta humanizada a partir da experiência estética, do "miraculoso" prodígio do Belo sensivelmente materializado em Lascaux. O escopo da reflexão empreendida por Bataille convida-nos a penetrar no interior da caverna para lá vislumbrarmos com profunda nostalgia a nossa condição primordial. Nessa perspectiva, parece bastante natural que esteja em jogo não apenas a identificação das nossas origens, ou seja, da nossa antropogénese, mas também a consideração da verdadeira forma de narrá-la. É interessante notar que ao narrar as pinturas rupestres a partir das quais um mundo a significar é alçado à condição de mundo significado, nosso autor tem em vista a natureza interacional da linguagem, visto que, esse mundo significado situa-se na esfera de uma encenação narrativa. Na medida em que nos permite ver e pensar o mundo em sua antropogénese com um olhar fixo (grifo nosso) nas pinturas da caverna de Lascaux, o modo como Bataille organiza a narrativa possibilita a sua aproximação com o leitor (que é o destinatário da narrativa), por meio de estratégias enunciativas que incluem o modo pelo qual o filósofo se relaciona com o que foi narrado. Tais estratégias podem exemplificar muito bem o drama filosófico que Bataille tem em mente, pois, ele apela à imaginação e aos sentimentos tanto quanto ao intelecto do leitor, combinando o rigor especulativo com as respostas sensíveis às demandas particulares da experiência estética primordial retratada em Lascaux. Assim, se nós, leitores de Bataille concordarmos sobre as condições que motivaram a realização das pinturas, seremos levados pelos argumentos por ele apresentados a optar, por exemplo, por uma determinada concepção de imagem baseada na fruição estética enquanto "fonte do êxtase", excluindo outros esquemas que sejam divergentes dos recursos exclusivos do belo. A este respeito, a posição de Bataille é mais uma vez complexa. Muito embora proporcione uma caracterização bastante vívida da natureza irreconciliável e nostálgica da "animalidade em nós 
perdurável", ele tende a sugerir outra via de reconciliação, ou, melhor dizendo, outra via de redenção, que viabiliza o (re)equilíbrio entre a animalidade e a humanidade. Neste quadro redentor, a arte primogênita de Lascaux define através do protesto transgressor da ordem da natureza a essência de toda a obra de arte produzida pelo ser humano. Deste modo, a arte de Lascaux expressa na sua "essência" e na sua "prática" o fundamento "insurgente" de todas as formas de arte:

É o estado de transgressão que comanda o desejo, a exigência de um mundo mais profundo, mais rico e prodigioso, numa palavra a exigência de um mundo sagrado. A transgressão traduz-se sempre com formas prodigiosas como as formas da poesia e da música, da dança, da tragédia ou da pintura. As formas da arte não têm outra origem além da festa de todos os tempos; e a festa que é religiosa por ser sagrada, liga-se à ostentação de todos os recursos da arte. Não podemos imaginar uma arte independente do movimento que gera a festa. O recreio é, num ponto, a transgressão da lei do trabalho. A arte, o recreio e a transgressão só tem o seu encontro ligados num movimento único de negação da regularidade do trabalho" (BATAILLE, 2015, p. 55-56).

Essas considerações sobre o caráter transgressor da atividade estética nos permitem voltar ao problema da "descontinuidade" e da "nostalgia", se admitirmos que a perspectiva pretendida pelo olhar do filósofo mostra o caminho áspero que é preciso percorrer para se chegar à fruição estética e que revela o delicado problema das relações entre as interdições do mundo do trabalho e a ordem da natureza. O que se encontra por trás da argumentação e da narrativa da antropogénese que Bataille utiliza para interpretar as pinturas paleolíticas revela as condições que envolvem a difícil conciliação entre o interdito e a transgressão a partir do momento em que a arte se manifesta como festa, fonte do êxtase que temporariamente é capaz de nos libertar de todos os constrangimentos impostos pela necessidade e de revelar, condignamente, como se deu a passagem do animal ao homem.

Ao filósofo cabe, portanto, o exercício de ultrapassar os limites da analogia figurativa e conceber as imagens paleolíticas como um complexo sistema de signos. Tudo leva a pensar que as pinturas rupestres não são somente os animais que representam, elas se servem das imagens dos animais para falar de outra coisa. Ou, formulando de outra maneira, podemos dizer que Bataille se apropria das formas dos animais para através delas definir a "condição humana". Essa formulação ganha ainda maior relevância quando a articulamos com as virtudes da "condição da poesia" que, segundo o filósofo, carrega, simultaneamente, o poder de descrever a antropogénese e o poder de entrever um mundo pré-antropológico, onde o olho do animal seria o único a se abrir diante das coisas (Bataille, 2015, p.128).

Assim se explica, porventura, a importância concedida por Bataille ao poder transgressor da poesia, visto que, somente a poesia consegue mostrar à consciência como contemplar os limites do humano e como olhar a vida animal da qual somos resultantes.

É necessário agora voltar a Nemésio. Nessa atmosfera paleolítica marcada pela constituição do humano, interessame discutir o estatuto da animalidade e sua relação com a representação poética da zoo antropogénese no território da 
escritura nemesiana. Tendo em vista o quadro rupestre da antropogénese e da arte animalista narradas por Bataille, podemos dizer que Nemésio espraia a sua fauna nos mais diversos textos em prosa e em verso, construindo uma verdadeira zoografia açoriana 7 . Pondo-nos em contato com uma imagem mítica e histórica das ilhas açorianas, fazendo-nos conhecer pela "força mitogénica da sua escrita," como demonstra o professor Machado Pires, o mito do homem açoriano sem ancestrais, do "início ab ovo do homo azorensis", Nemésio rompe os limites entre o animal e o humano, o vivo e o não vivo ${ }^{8}$. Como ocorre em seu Espelho, poema d'O Bicho Harmonioso, onde Nemésio vê-se "rastejante como um verme", "roído" como um "fruto seco", "cheio de pêco/semente estéril de tudo" e confessa intrigado: "Mas

\footnotetext{
7 Lembremos que, etimologicamente, o termo zoografia designava em grego antigo a imagem empírica e a imagem estética, ou seja, a pintura dos seres vivos, indicando que a animalidade emerge de uma complexa coordenação de ações entre todos os viventes sem que haja distinção hierárquica. A isso se segue a demarcação com o campo etimológico correspondente ao termo biós empregado, desde Heródoto, para indicar a duração cronológica e as especificidades das várias formas de vida. Os termos zoologia e biologia, constantemente utilizados para demarcar as ciências dedicadas ao conhecimento dos animais e de todos os viventes, são considerados neologismos modernos. Cf. Chantraine, 1987, p. 782-784.

8 Em Rouxinol e Mocho, o professor Machado Pires aborda, a partir do mito de Monsieur Queimado, a imagem mítica dos Açores e a concepção de açorianidade em Nemésio. Cito: "Na sua teoria, M. Queimado explicava que a ilha Terceira, sensivelmente equidistante de Bordeux, da terra Nova e de Cabo Verde, faz que os Açores não pertençam rigorosamente nem à Europa, nem à América, nem à África, mas simplesmente à sua própria identidade telúrica. (...) Afastada então a teoria geogenética dos Açores oriundos da Atlântida submersa, o mito de Monsieur Queimado gera uma outra teoria, a do homo azorensis, com a sua morfologia de conduta, "c'est à dire tout ce qui, parmi les différentes fonctions des organes, y compris les facultes et les agentes de notre âme, represente la seule adaptation possible à un but que l'individu est force de poursuivre".

O mito de M. Queimado é, afinal, o mito explicativo das origens, o mito das origens elas mesmas, do início ab ovo do homo azorensis (2009, p.67-68). Convém observar que Monsieur Queimado é um alter ego do poeta e, curiosamente, o nome Queimado é a alcunha açoriana do pássaro Milhafre.
}

não sei qual a voz que vem dizer-me/Que sou humano como tu".

A rasura dos reflexos do ser do poeta enfatiza ainda mais a sua meditativa perplexidade ao constatar que nada tem uma identidade plena, nada é e tudo se torna. $\mathrm{O}$ poeta convive com a alteridade no limite do suportável ao fazer-se verme, animal que ocupa o último lugar na escala de valores atribuídos pela biologia aos viventes e assim sinaliza para um território ilimitado quando nos remete ao enigma do impessoal que nele habita na forma de "fruto seco" de "semente estéril". Tudo está em latência, tudo é potencialmente capaz de tornar-se animal do humano, em signo enigmático da sua antropogénese, como ocorre no poema $O$ Bicho Harmonioso, que dá título ao livro, e, no qual, o poeta toma a poesia como tema, preocupado em alcançar a perfeição estética. E, tal como na tradição da mais antiga poesia, Nemésio busca a perfeita simetria entre natureza (phýsis) e arte (tekhné), vocação e técnica. Busca aglutinada na esfera da animalidade e que ele expressou nos versos que encerram o poema:

Separado de mim e do meu bafo individualmente podre,

Livre das minhas pretensões e desta noite carcomida

Pelo meu ser voraz que se explora e ilumina.

Do canto necessário

Para me diluir em som e no ar que o guardasse

Não chego a soltar senão uma vaga nota, E a noite faz muito bem em vergar uma gruta sem ecos

No meu buraco vil de bicho harmonioso.

Deixarei, estampada pelo silêncio definitivo,

A ramagem fremente dos meus dedos num pouco de terra -

Estranho fóssil! 
Eis um conjunto de insólitas imagens feitas de cruzamentos, entrecruzamentos e muitas encruzilhadas que seguem rumo ao rastro fossilizado do bicho poeta: bicho "voraz", por ser selvagem, "harmonioso", por ser domesticável. É nessa relação intrincada que se indicia e se inicia a aproximação entre o poeta e seu alter ego animal e que será explorada no decorrer de todo o livro. Destacaria que nos derradeiros versos acima citados o que, a meu ver, está em causa é o desenlace antagónico e pulsante do primeiro verso do poema.

Voltemos, então, de forma breve, ao seu início, onde Nemésio solenemente declara:

- "Eu gostava de ter um alto destino de poeta".

Esta declaração articula-se na perfeição com a reverberação das imagens antagónicas que conduzem o poeta ao recolhimento na sua "gruta sem ecos", lugar simbólico que concede expressividade eficaz aos sentimentos, ideias e juízos de valor consagrados à necessidade atávica de exercer com mestria a atividade poética. $\mathrm{O}$ antagonismo em questão opera uma curiosa inversão na forma como Nemésio nos apresenta a sua arte poética e a faz corresponder ao seu mais nobre e mais agónico anseio que faz com que ele, após subir aos cumes da mais alta pretensão artística e civilizatória, desça vertiginosamente rumo ao seu "buraco vil de bicho harmonioso".

Significativamente, acredito que a importância desta articulação, aqui sugerida, entre a declaração solene do verso inicial e o desfecho do poema, está relacionada com a forma como o poeta se apropria da imagem do bicho harmonioso como parte integrante da estratégia por ele utilizada para calar o "canto necessário" e instaurar o "silêncio definitivo" do bicho contemplativo recolhido e guardado pelo tempo fugidio como fóssil estampado na "gruta sem ecos", a caverna de Lascaux nemesiana.

É nesse espaço do mutismo animal que o poeta imprime os restos fossilizados da sua existência biológica, exposta nas marcas dos dedos das suas mãos - "ramagem fremente", - imagem polimórfica de um ser quase bicho, quase planta, quase humano e que serve para ornamentar a sua grutacaverna. É como se nesse cenário rupestre o núcleo descarnado da inspiração poética estivesse insistindo em construir uma significação durável para além do plano da linguagem. Mas que arte poética poderia dar conta de exigir relações tão complexas que obrigam o poeta a buscar o silêncio e o mutismo irredutível da animalidade? E, sobretudo, que poética é essa que se aproxima arriscadamente de um canto desprovido de sons e de palavras? Por que o exercício da atividade poética aparece como um horizonte onde o poeta foge para fora de si mesmo?

Nessas condições aporéticas, o primeiro passo decisivo a dar para compor a Lascaux de Nemésio é tornar evidente o encadeamento da reflexão poética com os argumentos filosóficos sustentados por Bataille. Para esse fim, convém retornar à tese central de Bataille com relação ao problema do rompimento instituído pelo ser humano na ordem da natureza, ou seja, o problema da "descontinuidade" para fundamentar o tema da zoo-antropogénese nemesiana. Como indiquei mais acima, o filósofo argumenta que pelo trabalho e pela arte o homem separou-se definitivamente do animal. Seguindo o critério da antropogénese de Bataille, vimos que se o homem possui o domínio da técnica, o 
animal lhe é superior no "domínio mágico" por estar em contato direto com a natureza, afastado da "descontinuidade" que marca a condição humana. Tais reflexões filosóficas descrevem, a meu ver, o escopo das referências simbólicas que mobilizam o imaginário zoográfico de Nemésio, pois indicam que a sua escrita poética é potencialmente capaz de ultrapassar o problema da "descontinuidade" ao romper as fronteiras do humano para seguir rumo à assimilação unificadora e privilegiada da ordem da natureza. Neste sentido, compreender-se-á, então, que nos versos acima citados d'O Bicho Harmonioso a figuração conjunta e aproximada do animal e do humano delineia fronteiras de passagem que fazem da convivência entre eles um modo de indagação do vivente, para além de toda distinção, identidade ou subjetividade. O que se encontra por trás dessa indagação descreve um processo de adesão do poeta ao dilema filosófico da configuração do animal em comunidade com o humano. Configuração marcada pelo grau mais alto de intimidade possível que visa situar em um mesmo nível de protagonismo animais e humanos ao fazer da distinção entre uns e outros uma mutação constante marcada por uma instabilidade essencial, uma sujeição à mudança, uma dupla metamorfose, devida, entre outras coisas, ao uso mais inquieto do que sereno do enigma animal ${ }^{9}$.

É a partir desta convivência múltipla e íntima com o animal, compreendida

\footnotetext{
9 A importância da "metamorfose ontológica" foi assinalada pela professora Margarida Maia Gouveia em seu artigo "Vitorino Nemésio - "Ilha ao Longe", publicado na revista Arquipélago. Para ela, as "metamorfoses ontológicas" surgem no texto do poeta "a partir de uma coincidência de paradoxos" que nos conduzem aos "Absolutos da criação de Vitorino Nemésio, que consubstancia um universo de símbolos, experiências, sensações e vivências insulares" (Maia, 1988, p.76).
}

pelo poeta como alvo suscetível de ser atingido pelo próprio canto poético, que podemos enunciar mais uma afinidade entre a reflexão nemesiana e a reflexão filosófica. Essa questão relativa ao alcance zoo-ontológico da poesia, como vimos em Bataille, também se encontra em Nemésio. Ambos tomam a poesia como o recurso mais eficaz e capaz de nos despertar de nossa própria ignorância com relação à questão da diferença entre humano e não humano.

Observemos no célebre poema, $\mathrm{O}$ Canário de Oiro, um primeiro signo de tensão que visa dispor do silêncio e do murmúrio do bicho harmonioso, alter ego do poeta, em prol do projeto de falar e de escrever em nome e no lugar daquele que não fala e não escreve, cobrindo de versos e vozes o mutismo pulsante da animalidade.

Se deixo entrar este canário de oiro Que me espreita e debica

(Eu que sou ossos - a gaiola,

Débil passarinho loiro!

Eu, professor - como um menino de escola!) ...

Pois sim... Canta, Fica!

E então, para que tudo em mim se honre e execute

Voz, penas e dejectos

Do canário -

Dou-lhe - seus passeadores - os meus afectos,

As minhas veias duras para grades:

Dentro delas, contrário,

Ele se embeleze e lute.

Ai, que o canário é o meu sangue talvez!

Como numa espécie de entrecruzamentos do campo ilimitado do não humano, em Nemésio o "discurso zoomorfo" oscila entre "o não representável e a sua inevitável representação", como afirma Maria da Conceição Vilhena em 
seu instigante artigo Bestiário Nemesiano. Segundo Vilhena, Nemésio abole as fronteiras entre homem e animal tendo em vista a elaboração de "um processo de pesquisa existencial", onde há sempre uma fusão entre a "criação pura" e a "evocação de experiências vividas" (Vilhena, p. 240-247, 1988).

Pode-se então dizer que em Nemésio o mistério da diferença humana no plano poético da animalidade não é apresentado como mera analogia, não é um simples adorno dentro da composição textual. $\mathrm{O}$ que o poeta coloca em jogo ficcional não é como o homem se sentiria no lugar do animal, mas sim de que forma ocorre uma travessia inevitável pelo tornar-se animal do humano. O estranhamento de si mesmo define a radicalidade dessa experiência poética-filosófica que o leva a abrigar, dentro do seu corpo-gaiola, o canário de ouro que canta dentro das suas veias. Questão de devir e de tornar-se que sempre coloca em risco as identidades monolíticas e que confirma em seus poemas a experiência da visão privilegiada da ordem da natureza como realidade suprema. Por esta razão, a zoografia nemesiana é a expressão de um homem cindido que reconhece a sua descontinuidade, mas anseia contemplar sua profundidade animal. Contudo, não se trata de pregar um retorno ao tempo perdido da animalidade, mas de reconhecer que a humanidade é o resultado de uma síntese mal resolvida entre o animal e o humano, uma contradição insolúvel.

Voltemos a avizinhar Bataille e Nemésio. Há uma "lama" da qual saímos, disse Bataille que admitiu também que ela é "a animalidade durável em nós" reemergida do drama da inevitabilidade da sexualidade e da morte impostas pela ordem da natureza (Cf. supra, p. 11). Também nos versos de
Nemésio, até o cenário malfadado de uma natureza que inspira aversão pode ser objeto de uma reflexão poético-filosófica que não distingue modos de vida nem delineia hierarquias entre humano, animal ou orgânico. Mas, se o filósofo capta na lama desditosa da condição humana a ausência de individualidade diante da imperativa ordem da natureza, o poeta vê na intimidade enigmática da sua "Iama azeda" a fonte da experiência poética, fonte de onde emergem os poderes da linguagem verbal, anunciadora da soberana intimidade da vida interior.
A Minha Voz
"Vamos a ver se te levanto
Com estas palavras escuras
Que são a luz do meu canto...
Vamos a ver se pode ser...
Na minha lama azeda e quente
Crias a tua forma (...)
Vamos a ver se eu te crio,
A ti que me encheste de ser
E enches o escuro de confiança.
O farrapo de mim, a que se agarraram uns limos,
Lá no seu tanque pútrido mexe,
Lá vive e cria as suas bichezas.
Assim nos vimos,
Minha voz!
Assim o cabo do látego remexe
Bichos, limos, vozes, tristezas -
E tudo isto dentro de nós.

Fluem nesses versos palavras perturbadoras, dotadas de sonoridade lancinante e de impressões repugnantes. Há neles uma fartura de imagens oferecidas pelo poeta para descrever o conflito agonístico que precede o seu canto. Tais imagens difundem nos leitores a disposição pela espera, pela expectação do canto, mantendo em suspenso o desfecho tão (in)esperado. A expectação cria um 
clima de suspense, auxiliando o poeta a conduzir o leitor à apreciação do seu projeto emancipatório que o faz emergir da "lama azeda", onde habita como irreconhecível "farrapo", desfigurado e rebaixado em relação ao humano por viver do apodrecimento que cria "bichezas". O poeta, que cultiva "bichos, limos, vozes, tristezas", consegue expressar de forma corrosiva essa poesia estranha que trabalha arduamente desde dentro, virando ao avesso a voz, a língua e a linguagem literária. O jorro disseminativo da voz que o habita fertiliza e ilumina o campo estéril das penumbras do ser animal mais abjeto e reivindica o poema como seu reino absoluto $^{10}$. Desta forma, Nemésio mergulha no que é obscuro como se a palavra pudesse efetivamente eliminar a distância que o separa da enigmática intimidade das bichezas das suas entranhas, resgatando seu ser mais profundo, buscando a intimidade perdida.

É sob o signo de uma nostalgia, de uma busca por algo perdido, ainda que inalcançável que o poeta reavista, derradeiramente, o filósofo. Se, voltando-se à nostalgia da animalidade, Bataille pôde falar do drama antropogénico como se ele guardasse o sentido de um mundo que almejava escapar do esforço laborioso, da ordem fastidiosa do trabalho; Nemésio encontra na expressão da nostalgia o signo de uma antropogénese que realiza suas figurações estéticas, delineando formas

\footnotetext{
10 Reporto-me ao que José Martins Garcia chamou de "risco da audácia estética" ao afirmar que Nemésio "é um poeta que, à beira de perder-se, reencontra o fio condutor" que o direciona para um mosaico ontológico: "Não há maniqueísmo em Vitorino Nemésio. Há esforço no sentido duma destrinça dentro da permeabilidade de todas as coisas, dentro da aceitação de si mesmo como "um bocado podre e outro divino" (conforme se lê em "Para que me deixem"), sem que o podre e o divino constituam compartimentos estanques" (GARCIA, 1988, p. 54).
}

híbridas como as evocadas no livro $\mathrm{O}$ Cavalo Encantado.

\section{Poldro de Som}

"Meu poema a cavalo é um poldro de som.

Pégaso de atrelar, que narina o fareja? Vamos iguais na sela, é o mesmo dom: Centauro, filho da inveja!

A nostalgia nemesiana sinaliza, simultaneamente, certo recalque mesclado com certo apelo, ou chamado que o poeta experimenta diante do cavalo. O poeta sente-se condenado a ser um eterno centauro, metade humano, metade animal, fazendo com que os papéis pré-fixados se "inter-troquem" e se interroguem, convocando o leitor para se metamorfosear ao utilizar o poema como dispositivo de passagem que possibilita experimentar um devir que não se consolida numa nova identidade. Reencontramos o mesmo tom nostálgico no poema Apoio, onde lemos:
(...) "O que lhe digo ao ouvido
Tudo executa, de manso.
Então, como não estimar
Cumplicidade tão doce:
Este amor, este confiar,
Como se eu cavalo fosse?
E o velho tom desta poesia, Que assim se deixa acavalar,
Agradecendo-lhe, de guia,
$\mathrm{O}$ que de humano me quis dar.

Os versos citados falam por si: o que está em causa é o reconhecimento de certo valor do humano que habita o animal. É nessa relação de partilha ontológica e de condição psicológica que se move a desconstrução não niilista do humanismo em direção a uma convivência redentora e esperançosa entre homem e animal. O que merece reparo na afetuosa convivência que 
envolve o poeta e o seu cavalo encantado, diz respeito aos sentimentos ordenadores que indicam a disposição do animal para agir com zelo, sabedoria e prudência. Dessa perspectiva, acredito que o poema celebra a fraternidade do animal com o humano.

Para concluir, gostaria de sublinhar que nossas leituras nos colocaram agora em posição de passarmos da inicial posição aporética para a fronteira da interpretação crítica. Situo esta minha aposta interpretativa num contexto em que a reflexão crítica sobre a figuração aproximada do animal e do humano realça sensivelmente a importância das posições estéticas assumidas por Nemésio. Uma característica nítida desta tendência está patente no modernismo literário presencista, com o qual Nemésio colaborou e diz respeito ao que se pode chamar, segundo Fátima Morna, "instinto catacrético do universo nemesiano" (1989, p.XXIV). Nemésio, contemporâneo do surrealismo, imprimiu nos poemas aqui mencionados a marca da "tradição da ruptura" alicerçada nas tendências estéticas caracterizadas, sobretudo, pela "flexibilização da articulação imagética". Como nos mostra Morna: "o golpe de mestre de Nemésio consiste em ter sintonizado perfeita e totalmente com o tempo estético que lhe foi dado viver, tempo em si mutável como todo o tempo é, sinónimo da própria mutabilidade" (1989, p. XXII).

Quem melhor que Nemésio poderia responder a essas palavras? Com magnífico clamor, ele sentencia:

“Eu, na minha varanda de palavras, Tão nodoso e pendido como elas, Encho de tempo o coração, Esvazio de luz os meus olhos ardidos, E guardo... guardo coisas sem nome, Achados puros, de ninguém perdidos, De que vou devagar abrindo mão".

\section{Referências}

\section{Fontes primárias}

NEMÉSIO, Vitorino. O Bicho Harmonioso. Porto: Imprensa Portuguesa, 1938.

Obras completas: Poesia 1916-1940 (v. I). Lisboa: Imprensa Nacional Casa da Moeda, 2006.

Obras completas: Poesia (v. II). Lisboa: Imprensa Nacional Casa da Moeda, 1989.

. Era do Átomo, Crise do Homem. Obras

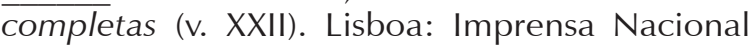
Casa da Moeda, 2003.

. Sob os Signos de Agora. Obras completas (v. XIII). Lisboa: Imprensa Nacional Casa da Moeda, 1994.

Corsário das Ilhas. Obras completas (v. XVI). Lisboa: Imprensa Nacional Casa da Moeda, 1996.

BATAILLE, Georges. Lascaux ou o nascimento da Arte. Tradução Aníbal Fernandes. Lisboa: Sistema Solar, 2015.

\section{Fontes secundárias}

CHANTRAINE, Pierre. Dictionnaire Etymologique de la Langue Grecque histoire des mots. Paris: Éditions Klincksieck, 1987.

ENES, José. Alegoria e Metáfora na obra poética de Vitorino Nemésio. In: NEMÉSIO, Vitorino. Vinte anos depois - Actas do Colóquio Internacional. Lisboa-Ponta Delgada: Ed. Cosmos, 1998.

FONTENAY, Elisabeth. Le Silence des Bêtes: la philosophie à l'éprouve de I'animalité. Paris: Fayard, 1998.

GARCIA, José Martins. Memória e Terapia em dois poemas de Vitorino Nemésio. In: NEMÉSIO, Vitorino. Vinte anos depois - Actas do Colóquio Internacional. Lisboa-Ponta Delgada: Ed. Cosmos, 1998.

GRAY, Jhon. Sobre Humanos e outros animais. Tradução Miguel Serras. Lisboa: Leya - Lua de Papel, 2017.

KECK, Frédéric. Le primitif et le mystique chez Lévy-Bruhl, Bergson et Bataille, Methodos. [En ligne], 3 | 2003, mis en ligne le 05 avril 2004, consulté le 03 juin 2018. URL: < http://journals. openedition.org/methodos/111>.

LESTEL, Dominique. A animalidade, o humano e as "Comunidades híbridas". In: MACIEL, Maria Esther (Org.). Pensar/Escrever o Animal: ensaios de zoopoética e biopolítica. Florianópolis: Editora da UFSC, 2011. 
MACHADO PIRES, A. M. B. Rouxinol e Mocho. Lisboa: Imprensa Nacional Casa da Moeda, 2009.

MACIEL, Maria Esther (Org.). Pensar/escrever o animal: ensaios de zoopoética e biopolítica. Florianópolis: Editora da UFSC, 2011.

Exercícios de zooliteratura. ComCiência, Campinas, n. 134, 2011.

MAILLARD-CHARY, Claude. Le bestiaire des surréalistes. Paris: Presses de la Sorbonne Nouvelle, 1994.

MAIA, Maria Margarida. Vitorino Nemésio - Ilha ao Longe. Arquipélago, v. X, p. 63-76, 1988.
NEVES, Márcia. Zooficções. Lisboa: Editora IELT, 2016.

ONFRAY, Michel. Cosmos: une ontologie matérialiste. Paris: J'ai Lu, 2017.

VILHENA, Maria da Conceição. Bestiário Nemesiano. Arquipélago, v. X, p. 233-247, 1988.

Recebido: 21 de novembro de 2018

Aceito: 17 de dezembro de 2018

ANNA SILVA

Desenvolve pesquisa de pós-doutorado no Centro de Estudos Humanísticos da Universidade dos Açores. Bolsista da Direção

Regional da Ciência e Tecnologia do Governo dos Açores.

(D) https://orcid.org/0000-0003-4552-189X

<anna.c.silva@uac.pt> 